\title{
Analisis Pelaksanaan Evaluasi Pembelajaran Berbasis Tematik di Madrasah Ibtidaiyah Kabupaten Rejang Lebong
}

\author{
Susilawati \\ Institut Agama Islam Negeri (IAIN) Curup \\ susilawatistaincurup2017@gmail.com \\ Syaripah \\ Institut Agama Islam Negeri (IAIN) Curup \\ Syana1401@gmail.com
}

\begin{abstract}
This study uses this type of research is qualitative research by conducting field surveys on the implementation of thematic-based learning evaluations. The subject of this study used a purposive sample of all Rejang Lebong Madrasah (MI) Districts consisting of 4 (four) state schools and 8 (eight) schools with private status. It is known that the results of his Thematic RPP are categorized as "Good", then the Thematic RPP Implementation has also been in the "good" category. Forms of assessments and thematic based assessments on K-13 have not met the criteria, only 1 school can show its documentation.
\end{abstract}

Key Word: learning evaluations, thematic-based learning

Abstrak : Penelitian ini menggunakan jenis penelitian adalah penelitian kualitatif dengan melakukan survey lapangan terhadap pelaksanaan evaluasi pembelajaran berbasis tematik. Subjek penelitian ini menggunakan purposive sample yakni seluruh Madrasah Ibtidaiyah (MI) Kabupaten Rejang Lebong yang terdiri dari 4 (empat) madrasah berstatus negeri dan 8 (delapan) madrasah berstatus swasta. Diketahui hasil penelitiannya RPP Tematik sudah berkategori "Baik", selanjutnya Pelaksanan RPP Tematiknya juga sudah pada kategori "baik". Bentuk penilaian dan penilaian berbasis tematik pada K-13 belum memenuhi kriteria hanya terdapat 1 madrasah yang dapat menunjukkan dokumentasinya.

Kata Kunci : Evaluasi Pembelajaran, Pembelajaran Tematik.

\section{PENDAHULUAN}

Kurikulum 2013 disiapkan untuk mencetak generasi yang siap di dalam menghadapi masa depan. Karena itu kurikulum disusun untuk mengantisipasi perkembangan masa depan. Sejalan dengan pengembangan kurikulum 2013 secara filosofis berlandaskan : filosofis pancasila yang memberikan berbagai prinsip dasar dalam pembangunan pendidikan dan filosofis pendidikan yang 
berbasis pada nilai-nilai luhur, nilai akademik, kebutuhan peserta didik dan masyarakat. ${ }^{1}$ Pendidikan nasional berfungsi mengembangkan dan membentuk watak serta peradaban bangsa yang bermartabat dalam rangka mencerdaskan kehidupan bangsa (UU RI Nomor 20 tahun 2003 tentang Sistem Pendidikan Nasional). Pendidikan berfungsi mengembangkan segenap potensi peserta didik "menjadi manusia yang beriman dan bertakwa kepada Tuhan Yang Maha Esa, berakhlak mulia, sehat, berilmu, cakap, kreatif, mandiri dan menjadi warga negara yang demokratis serta bertanggungjawab". ${ }^{2}$

Penyusunan kurikulum 2013 yang menitik beratkan pada penyederhanaan, tematik-integrative mengacu pada kurikulum 2006 di mana ada beberapa permasalahan di antaranya :

“ (i) konten kurikulum yang masih terlalu padat, ini ditunjukkan dengan banyaknya mata pelajaran dan banyak materi yang keluasan dan tingkat kesukarannya melampaui tingkat perkembangan usia anak; (ii) belum sepenuhnya berbasis kompetensi sesuai dengan tuntutan fungsi dan tujuan pendidikan nasional; (iii) kompetensi belum menggambarkan secara holistik domain sikap, keterampilan, dan pengetahuan; beberapa kompetensi yang dibutuhkan sesuai dengan perkembangan kebutuhan (misalnya pendidikan karakter, metodologi pembelajaran aktif, keseimbangan soft skills dan hard skills, kewirausahaan) belum terakomodasi di dalam kurikulum; (iv) belum peka dan tanggap terhadap perubahan sosial yang terjadi pada tingkat lokal, nasional, maupun global; (v) standar proses pembelajaran belum menggambarkan urutan pembelajaran yang rinci sehingga membuka peluang penafsiran yang beraneka ragam dan berujung pada pembelajaran yang berpusat pada guru; (vi) standar penilaian belum mengarahkan pada penilaian berbasis kompetensi (proses dan hasil) dan belum secara tegas menuntut adanya remediasi secara berkala ; dan (vii) dengan KTSP memerlukan dokumen kurikulum yang lebih rinci agar tidak menimbulkan multi tafsir".

\footnotetext{
${ }^{1}$ E. Mulyasa, Pengembangan dan Implementasi Kurikulum 2013 (Bandung : PT Remaja Rosdakarya, 2013) hlm., 64

${ }^{2}$ Kementerian Pendidikan dan Kebudayaan, Kurikulum 2013 ; Rasional, Kerangka Dasar, Struktur, Implementasi dan Evaluasi Kurikulum (Jakarta : Kemendikbud, 2013), hlm., 33 WIB

${ }^{3}$ http://www.kemdiknas.go.id/kemdikbud/, Kamis, 19 Oktober 2017, Pukul 14.12
} 
Perubahan kurikulum tersebut, khusus untuk jenjang Sekolah Dasar (SD) / Madrasah Ibtidaiyah (MI) mengalami banyak perubahan standar isi kurikulum. di SD/MI akan diterapkan sistem pembelajaran berbasis tematikintegrative. Banyak yang mempertanyakan dengan sikap pemerintah dalam hal ini Kementerian Pendidikan dan Kebudayaan (Kemendikbud) yang melakukan perubahan kurikulum. Di kalangan masyarakat atau pendidik memang sudah sering terdengar jika ganti menteri maka akan juga ganti kurikulum. Kontroversi terhadap perubahan kurikulum ini terus bermunculan.

Untuk tingkat SD terjadi perubahan yang cukup besar. Pada SD yang dulunya ada 10 mata pelajaran dikurangi menjadi 6 mata pelajaran yaitu empat mata pelajaran utama (PPKn, Agama, Bahasa Indonesia, dan Matematika) dan dua mata pelajaran muatan lokal (Seni Budaya dan Penjaskesorkes). Hal ini berimbas dengan evalusai pembelajaran, dimana guru telah terbiasa menggunakan KTSP yang menitik beratkan kepada kognitif dan tes menjadi cara penilaian yang dominan. Berbeda dengan pembelajaran Tematik-integrative yang berfokus pada tema namun penilaiannya berdasarkan proses, menekankan pada aspek kognitif, afektif dan prikomotorik serta penilaian test dan portofolio saling melengkapi.

Berdasarkan observasi yang dilakukan di MIS Guppi No.13 Tasik Malaya ditemukannya guru masih kesulitan menerapkan sistem evaluasi pembelajaran yang diterapkan pada K-13. Hasil wawancara dengan sekretaris KKG juga sejalan dengan pernyataan sebelumnya, masih banyak guru yang belum siap untuk melaksanakan atau menjalankan kurikulum 2013 dimana mereka kesulitan dalam proses penilaian. Dimana guru kebanyakan belum bisa memahami proses penilaiannya. Itu terlihat pada Bulan September 2017 tim KKG dari MI se-Kabupaten Rejang Lebong mengadakan pertemuan untuk membahas evaluasi pembelajaran yang seharusnya di terapkan pada Kurikulum 13. Berdasarkan survey dan wawancara juga diperoleh bahwa seluruh Madrasah Ibtidaiyah yang ada di Kabupaten Rejang Lebong belum $100 \%$ menerapkan pembelajaran tematik. Madrasah Ibtidaiyah menerapkannya di kelas Rendah (1 -3) sedangkan kelas tinggi $(4-6)$ belum menerapkannya.

Pendidikan Guru Madrasah Ibtidaiyah (PGMI) STAIN Curup merupakan wadah penyelenggaraan pendidikan dan pengajaran, menjadi konselor/pendamping pendidikan ilmu dasar MI/SD pada berbagai lembaga lembaga pendidikan, melakukan penelitian dalam rangka mengembangkan ilmu di bidang pendidikan MI/SD dan meningkatkan peran serta dan kerjasama dengan berbagai pihak masyarakat untuk mempersiapkan lulusan pada bidang Pendidikan Dasar Islam. 
Tujuan Program Studi PGMI STAIN Curup adalah menghasilkan guru kelas MI/SD berkualitas yang memiliki kompetensi pedagogik, kepribadian sosial, professional, leadership dan spiritual pada pendidikan tingkat dasar ; menghasilkan konselor anak usia MI/SD yang kompeten berwawasan IPTEKS dan mampu mengemban tugas- tugas pendidik pada jenjang dasar yang berlandaskan nilai-nilai islami ; menghasilkan pelatih (trainer) pendidikan $\mathrm{MI} / \mathrm{SD}$ yang handal ; menghasilkan peneliti yang produktif dan inovatif pada bidang pendidikan dasar MI/SD ; menghasilkan perancang sarana pembelajaran untuk pendidikan dasar MI/SD yang terampil entrepreunership ; menghasilkan tenaga pendidik yang dapat berperan aktif dalam lembaga pendidikan dan masyarakat sekitar. ${ }^{4}$

Perbaikan evaluasi pembelajaran berbasis tematik di MI merupakan salah satu tujuan Program Studi PGMI yaitu dalam proses perkuliahan dosen lebih menekankan komponen pembelajaran tematik disetiap mata kuliah yang berkenaan dengan pembelajaran mata pelajaran misalnya pembelajaran matematika, pembelajaran IPA, pembelajaran IPS, pembelajaran PKn dan pembelajaran Bahasa Indonesia, sehingga diharapkan kurikulum 2013 seutuhnya dapat dilaksananakan. Karena tujuan dari kurikulum 2013 akan menghasilkan proses tidak hanya kognitifnya saja. Penelitian ini merupakan tindak lanjut bagi Prodi PGMI yang telah menuntut mahasiswa dengan kurikulum yang berlaku/diterapkan pada saat ini. Selanjutnya, untuk untuk perbaikan mutu Madrasah Ibtidaiyah. Pelatihan, bimbingan serta analisis permasalahan pada penelitian ini. Untuk itu, sebagai langkah ilmiah prodi PGMI perlu melakukan penelitian tentang analisis pelaksanaan evaluasi pembelajaran berbasis tematik di MI kabupaten Rejang Lebong. Maka, Madrasah Ibtidaiyah merupakan alasan mendasar untuk dijadikan sumber penelitian dalam pengembangan prodi PGMI.

\section{LANDASAN TEORI}

\section{A. Analisis Evaluasi Pembelajaran Berbasis Tematik}

1. Pengertian Analisis

Analisis penguraian suatu pokok atas berbagai bagiannya dan penelaah dan bagian itu sendiri serta hubungan antar bagian untuk memperoleh bagian yang tepat dan pemahaman arti keseluruhan. ${ }^{5}$ Analisis SWOT adalah identifikasi berbagai faktor secara sistematis untuk merumuskan strategi perusahaan. Analisis ini didasarkan pada logika yang dapat memaksimalkan kekuatan (strength) dan peluang (opportunity), namun secara bersamaan dapat

\footnotetext{
${ }^{4}$ Panduan Akademil 2017. STAIN Curup

${ }^{5}$ Kamus Bahasa Indonesia, 2004, hlm.,43
} 
meminimalkan kelemahan (weakness) dan ancaman (threats). ${ }^{6}$ Proses pengambilan keputusan strategi selalu berkaitan dengan pengembangan misi, tujuan, strategi dan kebijakan perusahaan. Dengan demikian, perencanaan strategi harus menganalisa faktor- faktor strategi perusahaan (kekuatan, kelemahan, peluang dan ancaman) dalam kondisi yang saat ini.

2. Evaluasi Pembelajaran Berbasis Tematik

a. Pengertian Evaluasi Pembelajaran

Evaluation as well it, is the systematic collection of evidence to determine whether in fact certain chaners are taking place in the individual studets - evaluasi sebagai kita lihat adalah pengumpulan kenyataan secara sistematis untuk menetapkan apakah dalam kenyataannya terjadi kenyataan terjadi perubahan dalam diri pribadi siswa.

Prinsip-Prinsip evaluasi meliputi : keterpaduan, keterlibatan siswa, koherensi, pedagogis dan akuntabilitis ${ }^{8}$.

Prinsip keterpaduan dalam evaluasi karena evalusi merupakan komponen integral dalam program pengajaran. Evaluasi tidak dapat berdiri sendiri dalam pelaksanaannya, begaimana mau mengevalusi kalau tidak jelas keberadaannya tujuan, materi dan metode pengajaran dalam suatu proses pelaksanaannya. Tyler dengan segi tiga yang mengintegrasikan antara tujuan pembelajaran, materi pembelajaran dan evaluasi pembelajaran. Dengan demikian, proses integrasi dan terpadu dalam upaya mencapai hasil evaluasi pembelajaran yang baik sangant diperlukan.

Stufflebeam membuat batasan (merumuskan) terlebih dahulu tentang pengertian evaluasi sebagai "educational evalution is the process of obtaining and providing useful information for making educational decisions" (Evaluasi pendidikan merupakan proses penyediaan/pengadaan informasi yang berguna untuk membuat keputusan dalam bidang pendidikan). ${ }^{9}$

Pembelajaran adalah kegiatan jamak karena melalui urutan dari penyusunan kurikulum, pembuatan analisis pengajaran, pembuatan analisis tingkah laku masukan

${ }^{6}$ Freddy Rangkuti, Analisis SWOT Teknik Membedah Kasus Bisnis, (Jakarta : PT. Gramedia, 2004), hlm., 18

${ }^{7}$ Ali Hamzah, Evaluasi Pembelajaran Matematika, (Jakarta : Raja Grafindo Persada), hlm.,13

${ }^{8}$ Suke Silverius, Evaluasi Hasil Belajar dan Umpan Balik, (Jakarta : Grasindo,1991), hlm.,11 -12

${ }^{9}$ Stufflebeam (dalam Setia Armawati dkk), Evaluasi Program Pembelajaran Tematik Integratif Kelas 1 Sekolah Dasar Pelita Bangsa, (Jurnal : FKIP UNILA, Lampung), hlm., 6 
dari ciri siswa, menetapkan strategi pembelajaran, melakukan kegiatan pembelajaran dan evaluasi hasil belajar. Sedangkan, Tematik adalah model pembelajaran terpadu yang menggunakan tema untuk mengaitkan beberapa mata pelajaran sehingga dapat memberikan pengalaman bermakna kepada siswa. ${ }^{10}$ Dari paparan dii atas disimpulkan bahwa evaluasi pembelajaran berbasis tematik merupakan suatu sadar untuk mendapatkan berbagai informasi secara berkala, berkesinambungan, menyeluruh tentang proses dan hasil dari pertumbuhan dan perkembangan yang telah dicapai oleh anak didik melalui proses pembelajaran.

b. Karakteristik Penilaian Berbasis Tematik

Penilaian dalam Kurikulum 2013 memiliki karakteristik sebagai berikut ${ }^{11}$

1. Belajar Tuntas

Asumsi yang digunakan dalam belajar tuntas adalah peserta didik dapat mencapai kompetensi yang ditentukan, asalkan peserta didik mendapat bantuan yang tepat dan diberi waktu sesuai dengan yang dibutuhkan. Untuk kompetensi pada kategori pengetahuan dan keterampilan (KI-3 dan KI-4)

2. Otentik

Memandang penilaian dan pembelajaran adalah dua hal yang saling berkaitan. Penilaian otentik harus mencerminkan masalah dunia nyata, bukan dunia sekolah. Menggunakan berbagai cara dan kriteria holistic (kompetensi utuh merefleksikan pengetahun, keterampilan dan sikap). Penilaian otentik tidak hanya mengukur apa yang diketahui oleh peserta didik, tetapi lebih menekankan mengukur apa yang dapat dilakukan oleh peserta didik.

3. Berkesinambungan

Penilaian yang dilakukan secara terus menerus dan berkelanjutan selama pembelajaran berlangsung. Tunjuanya adalah untuk mendapatkan gambaran yang utuh mengenai perkembangan hasil belajar peserta didik, memantau proses, kemajuan, dan perbaikan hasil terus menerus dalam bentuk penilaian proses dan berbagai jenis ulangan secara berkelanjutan (ulangan harian, UTS dan UAS)

4. Menggunakan teknik penilaian yang bervariasi

${ }^{10}$ Depdiknas (Dalam Trianto Ibnu Badar al-Tabany), Desain Pengembangan Pembelajaran Tematik, (Jakarta : Prenadamedia Group ,2015) hlm.,147

${ }^{11}$ Kementerian Pendidikan dan Kebudayaan, Panduan Teknis Penilaian di Sekolah Dasar, 2013, hlm : 5-6 
Teknik penilaian yang dipilih dapat berupa tertulis, lisan, produt, portopolio, unjuk kerja, projek, pengamatan dan penilaian diri.

5. Berdasarkan acuan kriteria

Penilaian didasarkan pada ukuran pencapaian kompetensi yang ditetapkan. Kemampuan peserta didik tidak dibandingkan terhadap kelompoknya, tetapi dibandingkan terhadap kriteria yang ditetapkan. KKM ditetapkan oleh satuan pendidikan masing-masing dengan mempertimbangkan karakteristik kompetensi dasar yang akan dicapai, daya dukung (sarana dan guru), dan karakteristik peserta didik.

c. Teknik Penilaian Berbasis Tematik di SD/MI

Penilaian di SD/MI dilakukan dalam berbagai teknik untuk semua kompetensi dasar yang dikategorikan dalam tiga aspek, yaitu sikap (muatan KI-1 dan KI-2), pengetahuan dan keterampilan. ${ }^{12}$

a) Sikap, penilaian aspek sikap spiritual (KI-1) dan sikap sosial (KI-2) dilakukan melalui observasi, penilaian diri, penilaian antar teman dan jurnal ; (b)Pengetahuan, aspek pengetahuan dapat diukur dengan cara tes tertulis ( subjektif maupun objektif), tes lisan dan penugasan (individu maupun kelompok);

(c) Kerampilan, aspek keterampilan dapat dinilai dengan cara kinerja atau performance, projek dan portofolio.

Pada pembelajaran tematik penilaian dilakukan untuk mengkaji ketercapaian kompetensi dasar dan indikator pada tiap-tiap mata pelajaran yang terdapat pada tema tersebut. Dengan demikian penilaian dalam hal ini tidak lagi terpadu melalui tema, melainkan sudah terpisah-pisah sesuai dengan kompetensi dasar, hasil belajar dan indikator mata pelajaran.

1. Penilaian Sikap

Penilaian aspek sikap dolakukan melalui observasi, [penilaian diri, penilaian anytarteman dan jurnal. Penilaian sikap ini bukan merupakan penilaian yang terpisah dan berdiri sendiri, namun merupakan penilaian yang pelaksanaannya terintegrasi dengan penilaian pengetahuan dan keterampilan, sehingga bersifar autentik (mengacu kepada pemahaman bahwa pengembangan dan penilaian KI 1 dan KI 2 dititipkan melalui kegiatan yang didesain untuk mencapai KI 3 dan KI 4). ${ }^{13}$

\footnotetext{
${ }^{12}$ Ibid., hlm 8-11

13 Rusman, Pembelajaran Tematik Terpadu (Teori, Praktik dan Penilaian),
} (Jakarta : Raja Grafindo Persada) hlm, 253 
a. Observasi

Teknik penilaian yang dilakukan nsecara berkesinambungan dengan menggunakan indra, baik secara langsung, baik secara langsung maupun tidak langsung dengan menggunakan format observasi yang berisi sejumlah indicator perilaku yang diamati, terkait dengan kegiatan pembelajaran yang sedang berlangsung.

b. Penilaian Diri

Teknik penilaian dengan cara meminta peserta didik untuk melakukan refleksi diri/perenungann dan mengemukakan kelebihan dan kekurangan dirinya dalam kontels pencapaian kompeternsi. Instrument yang digunakan lembar penilaian diri.

c. Penilaian Antarteman

Teknik penilaian dengan cara meminta peserta didik untuk saling terkait dengan sikap dan perilaku keseharian peserta didik selama kegiatan perbelajaran berlangsung (biasanya dilakukan ketika antar anggota kelompok) intrumen yang dilakukan berupa lembar penilaian antar peserta didik

d. Jurnal Catatan Guru

Catatan pendidik di dalam dan di luar kelas yang berisi informasi hasil pengamatan tentang kekuatan dan keleman peserta didik yang berkaitan dengan sikap dan perilaku. Jurnal bisa dikatakan sebagai catatan yang berkesinampungan dari hasil observasi.

2. Penilaian Pengetahuan

Aspek pengetahun dapat diniliai dengan cara berikut ini ${ }^{14}$ :

a. Tes Tulis

Tes tertulis terdiri dari memilih atau mensuplai jawaban dan uraian. Memilih jawaban dan mensuplai jawaban. Memilih jawaban terdiri dari pilihan ganda, pilihan benar-salah, ya - tidak, menjodohkan dan sebab akibat. Mensuplai jawaban terdiri dari isian atau melengkapi, jawaban singkat atau pendek dan uraian.

b. Tes Lisan

Tes lisan berupa pertanyaan-pertanyaan yang diberikan guru secara ucap sehingga peserta didik meresponj pertanyaan tersebut secara ucap juga, sehingga menimbulkan keberanian. Jawaban dapat berupa kata, frase, kalimat maupun paragraph yang diucapkan.

c. Penugasan

Penilaian yang dilakukan oleh pendidikan yang dapat berupa pekerjaan rumah baik secara individu ataupun kelompok sesuai karakteristik tugasnnya.

3. Penilaian Keterampilan

${ }^{14}$ Ibid, hlm,,254 
Aspek keterampilan dapat dinilai dengan cara berikut ${ }^{15}$ :

a. Penilaian Kinerja

Penilaian kinerja adalah suatu penilaian yang meminta siswa untuk melakukan suatu tugas pada situasi yang sesungguhnya yang mengaplikasikan pengetahuan dan keterampilan yang dibutuhkan. Misalnya tugas memainkan alat music, menggunakan mikroskop, menyanyi, bermain loeran dan menari

b. Penilaiaan Proyek

Penilaian proyek merupakan kegiatan penilaian terhadap tugas yang harus diselesaikan oleh peserta didik menurut periode/waktu tertentu.. penyelesaian tugas dimaksud berupa investigasi yang dilakukan oleh peserta didik, mulai dari perencanaan, pengu8mpulan data, pengorganisasian, pengolahan, analisisi dan penyajian data.

c. Penilaian Portofolio

Penilaian melalui sekumoulan karya peserta didik yang tersusun secara sistematis dan terorganisasi yang dilakukan selama kurun waktu tertentu. Portofolio digunakan oleh guru dan peserta didik untuk memantau secara terus menerus perkembangan pengetahuan dan keterampilan peserta didik dalam bisang tertentu.

\section{B. Penetapan Teknik Evaluasi Pembelajaran Tematik}

\section{Hakikat Evaluasi dalam Pembelajaran Terpadu}

Pembelajaran terpadu sama halnya dengan pembelajaran tematik. Dalam konteks pembelajaran terpadu maka evaluasi adalah proses sistematis pengumpulan, pengolahan dan penyimpulan informasi tentang proses dan hasil pembelajaran terpadu, untuk selanjutntya diberikan pertimbangan nilai atas proses dan hasil pembelajaran tersebut berdasarkan pada suatu kriteria tertentu.

Jadi yang menjadi objek evaluasi dalam pembelajaran terpadu secara umum proses dan hasil pembelajaran. ${ }^{16}$

\section{Aspek-Aspek yang menjadi Perhatian Penilaian dalam Pembelajaran Terpadu}

Ada sejumlah aspek yang menjadi perhatian penilaian, maksudnya yaitu hal-hal yang akan dinilai tingkat perubahan hasil belajarnya berupa kemampuan dan kemajuan yang dicapai. Aspek-aspek tersebut meliputi $:^{17}$

1. Aspek akademis. Aspek akademis yaitu berkaitan dengan penguasaan isi pelajaran.

2. Aspek pemikiran. Yaitu berkaitan dengan kemampuan kognitif dalam berbagai tingkatan. Merujuk pada penjelasan tingkatan

${ }^{15}$ Ibid, hlm 255-260

${ }^{16}$ Deni Kurniawan, Pembelajaran Terpadu Tematik (Teori, Praktik dan Penilaian), (Bandung : ALFABETA) hlm, 196

${ }^{17}$ Ibid, hlm 199-200 
kemampuan kognitif Bloom, kemampuan kognitif itu merentang dari kemampuan tingkat rendah hingga kemampuan kongnitif tingkat tinggi.

3. Aspek Keterampilan. Maksudnya yaitu aspek yang berkaitan dengan kemampuan motoric atau kemampuan yang bersifat jasmaniah

4. Aspek Sikap. Aspek sikap berkaitan dengan kualitas dan perubahan yang berkaitan dengan afeksi siswa.

5. Asoek kebiasaaan kerja. Ini berkaitan dengan daya tahan, konsistensi, dan pola kerja dalam penyelesaian berbagai tugas belajar.

\section{METODE PENELITIAN}

Pendekatan pada penelitian ini merupakan pendekatan kualitatif. Pendekatan kualitatif adalah penelitian yang lebih menekankan analisisnya pada proses penyimpulan induktif serta pada analisis terhadap dinamika hubungan antara fenomena yang diambil dengan menggunakan logika ilmiah. ${ }^{18}$

Dalam penelitian ini peneliti menggunakan metode purposive sampling, dimana pengambilan sampel dengan pertimbangan tertentu. Pertimbangan tertentu ini misalnya orang tersebut dianggap paling tahu tentang apa yang diharapkan, atau mungkin dia sebagai penguasa sehingga akan memudahkan peneliti menjajahi objek/situasi sosial yang diteliti. ${ }^{19}$ Jadi subjek penelitian ini adalah Kepala Sekolah MI dan Guru MI khususnya guru kelas di Kabupaten Rejang Lebong.

Tabel 3.1 Madrasah Ibtidaiyah Negeri / Swasta Kab. Rejang Lebong

\begin{tabular}{cllllc}
\hline No & Nama Satuan Pendidikan & \multicolumn{1}{c}{ Alamat } & Kelurahan & Status \\
\hline 1 & $\begin{array}{l}\text { MIS Muhammadiyah } 10 \\
\text { Karang Anyar }\end{array}$ & Jln. Syahrial & Karang Anyar & SWASTA \\
\hline 2 & $\begin{array}{l}\text { MIS Muhammadiyah 14 } 14 \\
\text { Talang Ulu }\end{array}$ & $\begin{array}{l}\text { Jln. Ahmad } \\
\text { Yani }\end{array}$ & Talang Ulu & SWASTA \\
\hline 3 & MIN 1 Rejang Lebong & Dusun Curup & Dusun Curup & NEGERI \\
\hline 4 & $\begin{array}{l}\text { MIS Guppi 12 Lubuk } \\
\text { Kembang }\end{array}$ & $\begin{array}{l}\text { Desa Lubuk } \\
\text { Kembang }\end{array}$ & $\begin{array}{l}\text { Tunas } \\
\text { Harapan }\end{array}$ & SWASTA \\
\hline 5 & $\begin{array}{l}\text { MIS Guppi No. 13 Tasik } \\
\text { Malaya }\end{array}$ & Tasik Malaya & $\begin{array}{l}\text { Tunas } \\
\text { Harapan }\end{array}$ & SWASTA \\
\hline 6 & $\begin{array}{l}\text { MIS Guppi No.11 } \\
\text { Rimbo Baru }\end{array}$ & TL. Jln. Cokro & $\begin{array}{l}\text { Talang Rimbo } \\
\text { Aminoto }\end{array}$ & SWASTA \\
\hline 7 & MIN 2 Rejang Lebong & $\begin{array}{l}\text { Kampung } \\
\text { Jeruk Kepala }\end{array}$ & $\begin{array}{l}\text { Kepala Curup } \\
\text { - Bindu Riang }\end{array}$ & NEGERI \\
\hline
\end{tabular}

${ }^{18}$ Saifuddin Azwae, Metode Penelitian (Yogyakarta : Pustaka Pelajar, 2007) hlm 5

${ }^{19}$ Sugiyono, Memahami Penelitian Kualitatif (Bandung : Alfabeta, 2014), hlm . 53 


\begin{tabular}{|c|c|c|c|c|}
\hline & & Curup & & \\
\hline 8 & MIN 3 Bandung Marga & $\begin{array}{l}\text { Bandung } \\
\text { Marga }\end{array}$ & $\begin{array}{lr}\text { Bandung } & \\
\text { Marga } & - \\
\text { Bermani Ulu } \\
\text { Raya }\end{array}$ & NEGERI \\
\hline 9 & MIS Nurul Huda & Belumai I & $\begin{array}{ll}\text { Belumai } & \text { I - } \\
\text { Pala } & \text { Ulak } \\
\text { Tanding } & \\
\end{array}$ & SWASTA \\
\hline 10 & MIS Ar-Rahmah & Jln. Pramuka & $\begin{array}{ll}\text { Air } & \text { Meles } \\
\text { Atas } & \\
\end{array}$ & SWASTA \\
\hline 11 & MIS Nurul Kamal & $\begin{array}{l}\text { Jln. Lingkar } \\
\text { Pesantren }\end{array}$ & Karang Jaya & SWASTA \\
\hline 12 & MIN 4 Rejang Lebong & Desa Derati & Derati & NEGERI \\
\hline
\end{tabular}

\section{A. Teknik Pengumpulan Data}

a. Observasi

Observasi dilakukan untuk memperoleh gambaran riil suatu peristiwa atau kejadian untuk menjawab pertanyaan penelitian. Adapun observasi yang dilakukan peneliti dalam hal ini adalah observasi partisipasi. Metode pengumpulan data yang digunakan untuk menghimpun data penelitian melalui pengamatan dan penginderaan dimana peneliti terlibat dalam keseharian informan. Adapun yang diobservasi dalam penelitian ini digunakan untuk memperoleh data yang sebenarnya proses pelaksanaan evaluasi pembelajaran berbasis tematik di MI Rejang Lebong. Adapun yang harus di observasi dalam penelitian ini adalah :

Tabel 3.2 : Pedoman Observasi Penelitian :

\begin{tabular}{llll}
\hline No & \multicolumn{1}{c}{ Indikator } & \multicolumn{1}{c}{ Aspek Yang Dinilai } \\
\hline 1. & Perencanaan & a. Tema \\
& Pelaksanaan & b. Indikator dan Tujuan \\
& Pembelajaran & c. Materi \\
& (RPP) Terpadu & d. Strategi \\
& (Tematik) & e. Media \\
& & f. Evaluasi \\
\hline 2. & Pelaksanaan & a. Membuka Pembelajaran \\
& Pembelajaran & b. Penyajian Materi \\
& Terpadu (Tematik) & c. Sikap Dan Pengelolaan Kelas \\
& & d. Penggunaan Media \\
& & e. Pengelolaan Proses Pembelajaran \\
& & f. Menutup Pembelajaran \\
& & g. Kesan Umum Pembelajaran \\
\hline 3. & Penilaian Sikap & a. Berdo'a Sebelum Dan Sesudah \\
& Spritual & & Melakukan Sesuatu \\
\hline
\end{tabular}




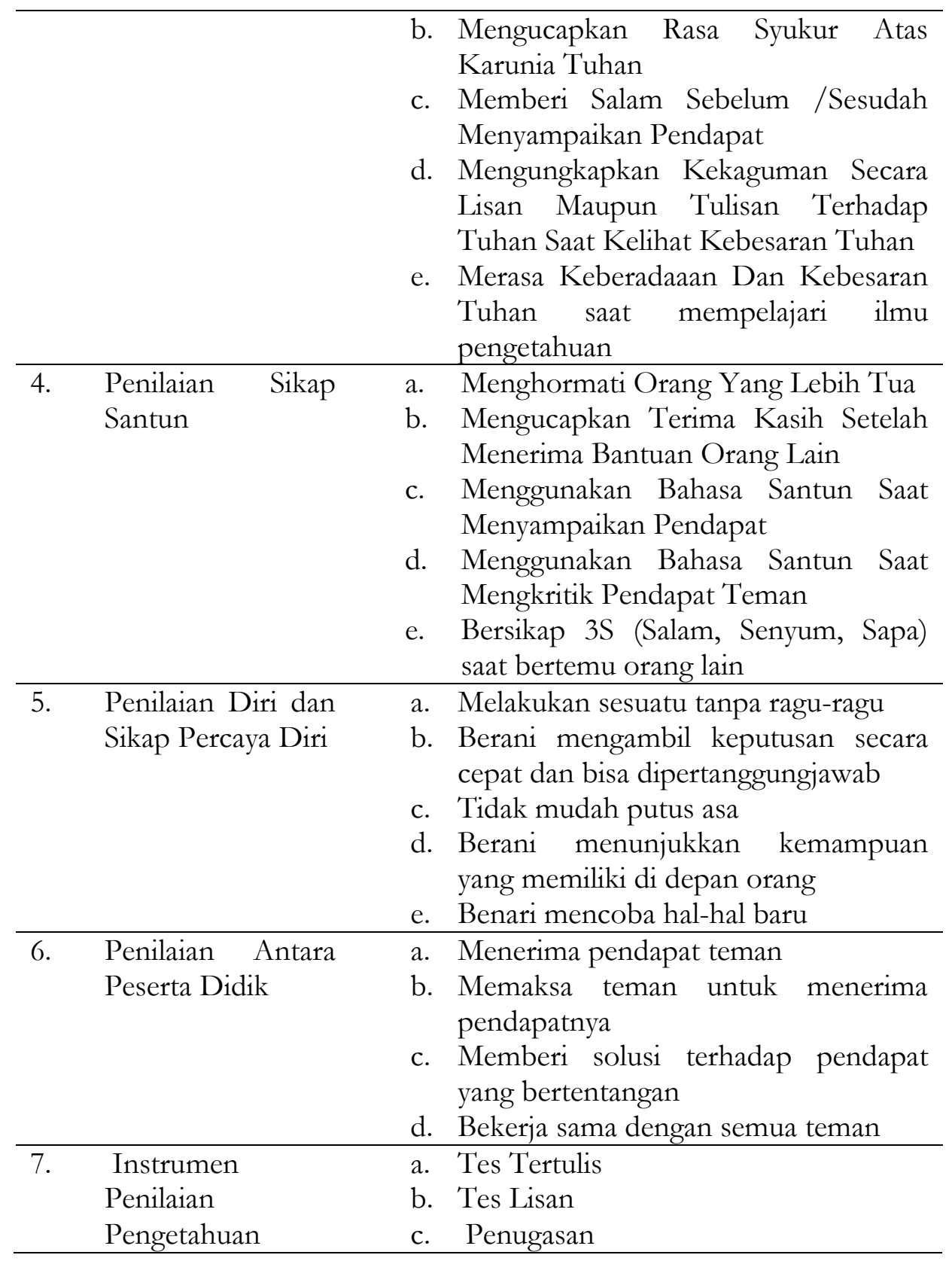

b. Wawancara

Wawancara merupakan kegiatan untuk memperoleh informasi secara mendalam tentang sebuah isu atau tema yang diangkat dalam penelitian ini. Atau merupakan proses pembuktian terhadap informasi atau keterangan yang telah diperoleh lewat teknik yang lain. Agar wawancara efektif maka terdapat tahapan yang harus dilalui yakni : 1) Mengenalkan diri ;2) Menjelaskan maksud kedatangan ; 3) Menjelaskan materi wawancara dan 4) Mengajukan pertanyaan. 
Dalam penelitian ini dilakukan wawancara semiterstruktur (Semistructure Interview) termasuk dalam kategori in-dept interview, dimana dalam pelaksanannya lebih bebas untuk menemukan permasalahan secara lebih terbuka, diman fihak yang diajak wawancarai dimintai pendapat dan ide-idenya. Dalam melakukan wawancara, peneliti perlu mendengarkan secara teliti dan memcatat yang dikemukakan oleh informan. Wawancara dalam penelitian ini dilakukan untuk memperoleh data mengenai kendala, respon yang dihadapi guru dalam evaluasi pembelajaran berbasis tematik.

Tabel 3.3 : Pedoman Wawancara

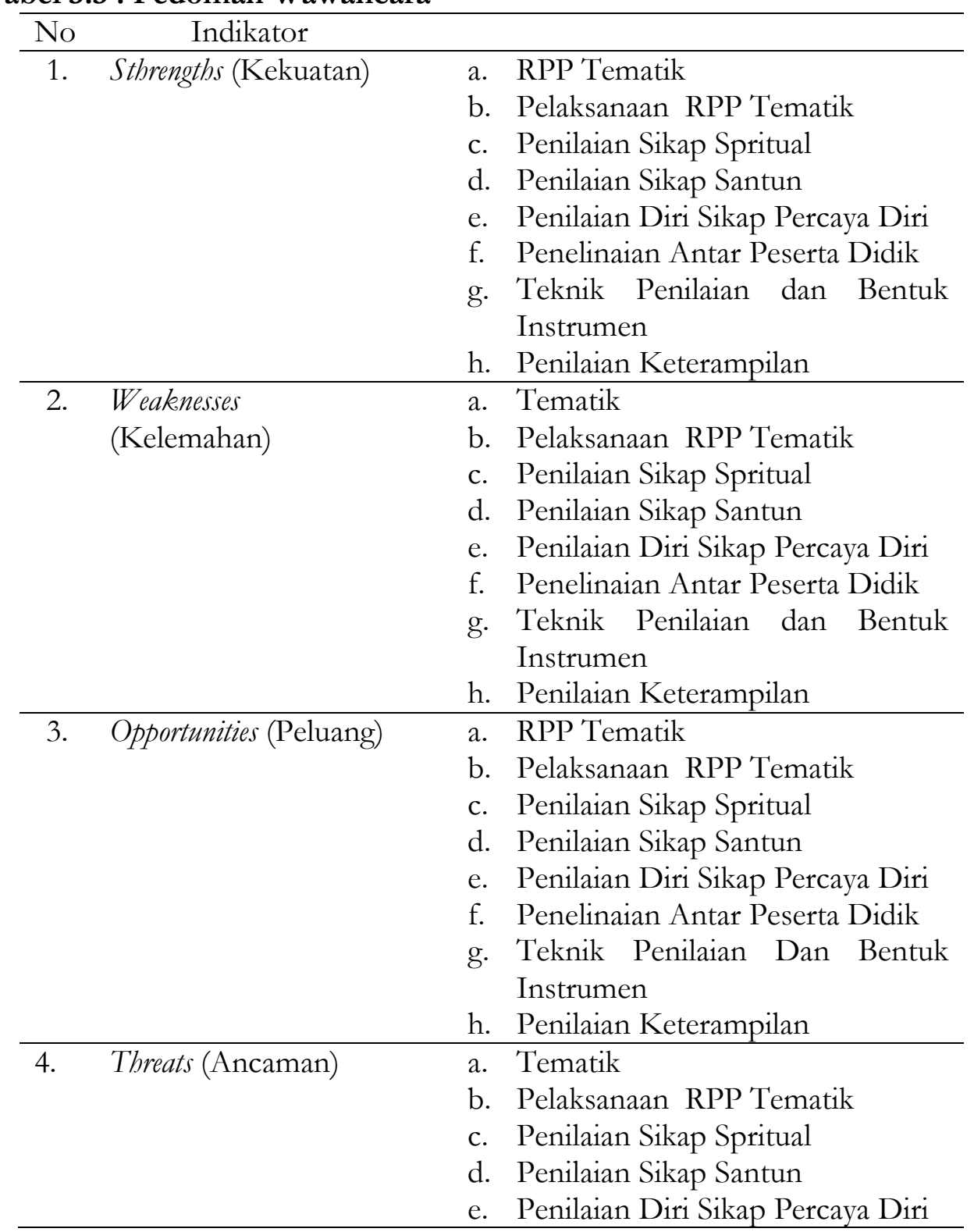




\begin{tabular}{ll}
\hline f. Penilaian Antar Peserta Didik \\
g. Teknik Penilaian dan Bentuk \\
Instrumen \\
h. Penilaian Keterampilan \\
\hline
\end{tabular}

c. Dokumentasi

Dokumentasi adalah pengumpulan data dengan melihat atau mencatat suatu laporan yang sudah tersedia. Metode dokumentasi merupakan mencari data mengenai variabel yang berupa catatan, transkrip, buku, surat kabar, majalah, prasasti, notulen rapat, agenda dan lain sebagainya. Dalam hal ini peneliti menjadikan dokumentasi sebagai alat pengumpul data dari bahan tertulis. Dokumentasi dalam penelitian ini berupa jenis penilaian, silabus, Rencana Pelaksanaan Pembelajaran, bahan ajar guru dan lain-lainnya. Adapun yang harus di dokumentasikan dalam penelitian ini adalah :

\section{Tabel 3.4 : Pedoman Dokumentasi}

\begin{tabular}{|c|c|c|}
\hline \multirow[b]{2}{*}{ No } & \multirow[b]{2}{*}{ Dokumentasi } & Tersedia \\
\hline & & Ada Tidak Ada \\
\hline 1. & 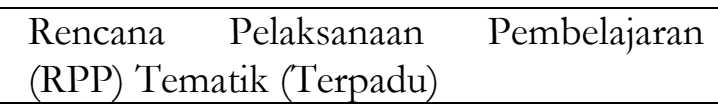 & \\
\hline & Penilaian Sikap Spritual & \\
\hline & Penilaian Observasi Sikap Santun & \\
\hline 4. & Penilaian Diri Dan Sikap Percaya Diri & \\
\hline 5. & Penilaian Antar Peserta Didik & \\
\hline & $\begin{array}{l}\text { Lembar Teknik Penilaian dan Bentuk } \\
\text { Instrument }\end{array}$ & \\
\hline 7. & Lembar Penilaian Keterampilan & \\
\hline & Lembar Jurnal & \\
\hline
\end{tabular}

\section{B. Teknik Analisis Data}

a. Data Reduction (Reduksi Data)

Mereduksi data berarti merangkum, memilih hal-hal yang pokok, menfokuskan pada hal-hal yang penting, dicari tema dan polanya. Dengan demikian data yang telah direduksi akan memberikan gambaran yang lebih jelas, dan memudahkan peneliti untuk melakukan pengumpulan data dibantu dengan peralatan elektronik seperti computer mini dengan memberikan kode pada aspek-aspek tertentu. ${ }^{20}$

b. Data Display (Penyajian Data)

Dalam penelitian kualitatif, penyajian data dapat dilakukan dalam bentuk table, grafik, phie chard, pictogram dan sejenisnya. Melalui penyajian data

${ }^{20}$ Sugiyono, Metode Penelitian Pendidikan : Pendekatan Kuantitatif dan Kualitatif dan $R \&$ \& , (Bandung : Alfabeta, 2011), hlm., 92 
tersebut, maka data terorganisasikan, tersusun dalam pola hubungan sehingga mudah dipahami. ${ }^{21}$

\section{c. Conclusion Drawing / V erification}

Kesimpulan awal yang dikemukakan masih bersifat sementara, dan akan berubah bila tidak ditemukan bukti-bukti yang kuat yang mendukung pada tahap pengumpulan data berikutnya. Tetapi apabila kesimpulan data yang dikemukakan pada tahap awal didukung oleh bukti-bukti yang valid dan konsisten saat penelitian kembali ke lapangan mengumpulkan data, maka kesimpulan yang dikemukanan merupakan kesimpulan yang kredibel. ${ }^{22}$

\section{HASIL PENELITIAN dan PEMBAHASAN}

\section{A. Hasil Penelitian}

Hasil penelitian berupa Sthrengths (Kekuatan), Weaknesses (Kelemahan), Opportunuties (Peluang), Threats (Ancaman), ditinjau dari pelaksanaan evaluasi pembelajaran berbasis tematik di MI kabupaten Rejang Lebong.

\section{a. RPP Tematik Madrasah Ibtidaiyah Kabupaten Rejang Lebong}

Berdasarkan hasil observasi yang dilakukan pada RPP salah satu guru di setiap Madrasah Ibtidaiyah (MI) menunjukkan dari segi tema kategori "baik" dengan nilai rata-rata 3,4, segi indicator dan tujuan kategori "baik" dengan ratarata 3,4, materi kategori "baik" dengan nilai rata-rata 3,2, Strategi memperoleh kategori "baik" dengan nilai rata-rata 3,3, media dengan kategori baik dengan nilai rata-rata 3,2 selanjutnta evaluasi memiliki kategori nilai baik dengan nilai rata-rata 3,5. Enam dari setiap indicator yang diamati secara keseluruhan sudah memenuhi kriteria baik dikarenakan data yang diamati diperoleh dr guru yang sudah menerapkan kurikulum 13 khususnya untuk pembelajarab tematik

\section{Grafik 4.1 : RPP Tematik Madrasah Ibtidaiyah Kabupaten Rejang Lebong}

\footnotetext{
${ }^{21}$ Ibid., hlm 95

${ }^{22}$ Ibid ., hlm 99
} 


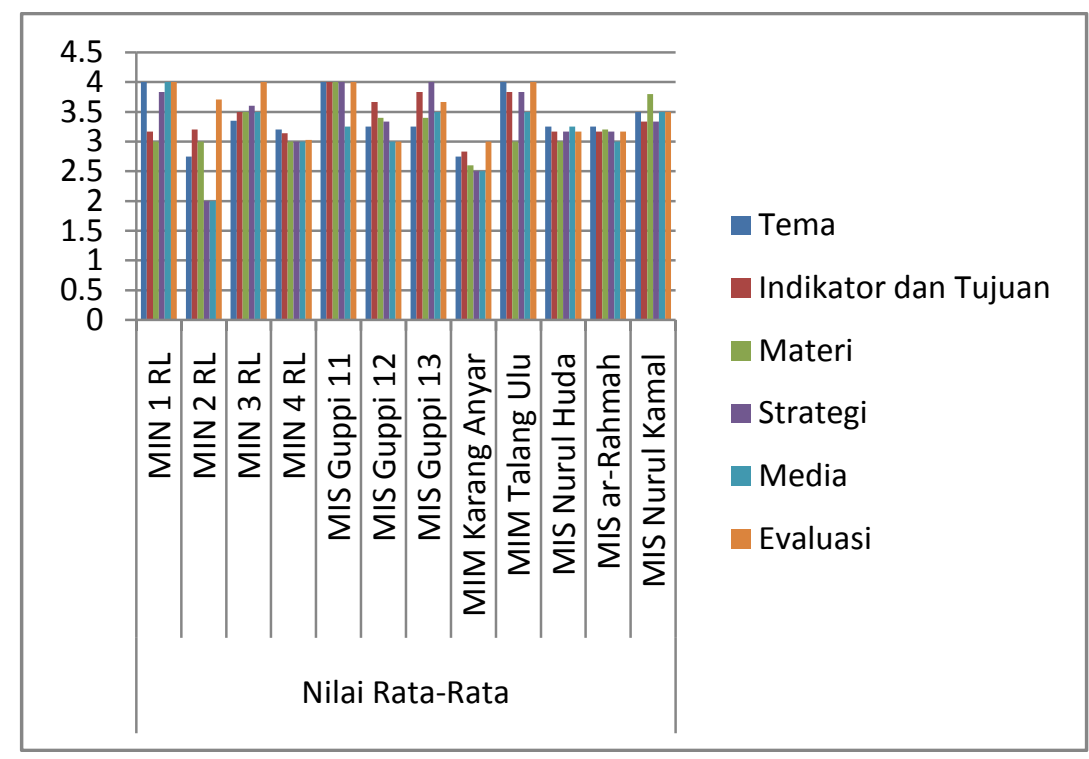

b. Pelaksanaan RPP Tematik Madrasah Ibtidaiyah Kabupaten Rejang Lebong

Berdasarkan hasil observasi yang dilakukan pada RPP salah satu guru di setiap Madrasah Ibtidaiyah (MI) menunjukkan dari segi membuka pelajaran kategori "baik" dengan nilai rata-rata 3,6, segi penyajian materi "baik" dengan rata-rata 3,4, indicator sikap dan pengelolaan kategori "baik" dengan nilai ratarata 3,5,penggunaan media memperoleh kategori "baik" dengan nilai rata-rata 3,4 , Penilaian proses pembelajaran dengan kategori baik dengan nilai rata-rata 3,3 selanjutnya menutup pembelajaran memiliki kategori nilai baik dengan nilai rata-rata 3,4. Indicator kesan umum pembelajaran dengan kriteria "baik" nilai rata-rata 3,5. Tujuh dari setiap indicator yang diamati secara keseluruhan sudah memenuhi kriteria baik dikarenakan data yang diamati diperoleh dr guru yang sudah menerapkan kurikulum 13 khususnya untuk pembelajarab tematik

\section{Grafik 4.2 : Pelaksanaan RPP Tematik Madrasah Ibtidaiyah Kabupaten Rejang Lebong}




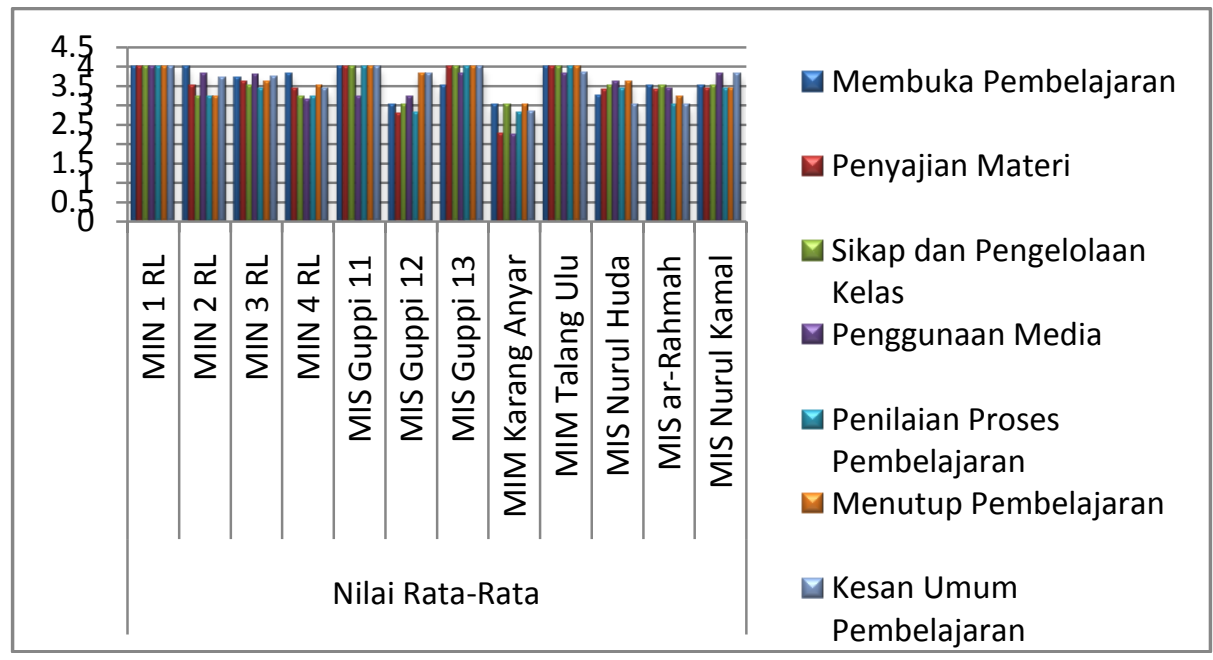

c. Penilaian Sikap Spritual, Penilaian Sikap Santun, Penilaian Diri Sikap Percaya Diri, Penilaian Antar Peserta Didik dan Penilaian Keterampilan Berdasarkan hasil wawancara pada salah satu guru setia guru Madrasah Ibtidaiyah Kabupaten Rejang Lebong secara garis besarnya mengenai penilaian sikap spritual, penilaian sikap santun, penilaian diri sikap percaya diri, penilaian antar peserta didik dan penilaian keterampilan adalah dengan adanya lembar observasi sikap spiritual, guru dapat mengetahui sejauh mana sikap spiritual yang dimiliki anak dikelasnya, siswa mulai menunjukkan sikap cara yang lebih baik (sopan santun, percaya diri), dengan adanya observasi sikap santun guru dapat mengetahui sikap anak, mana yang memiliki sikap santun mana yang tidak, siswa mulai memiliki sikap percaya diri dalam mengerjakan sesuatu hal yang baik dan guru mulai melihat kemampuan yang ada pada diri anak, siswa akan mengetahui kekurangan atau kelebihan diantara mereka yang demikian siswa yang merasa ada kekurangan akab berusaha memenuhi kekurangan tersebut, dan dengan adanya lembar penilaian keterampilan siswa, guru dapat mengetahui keterampilan anak didknya dalam mengajarkan tugas-tugas yang diberikan ( jika anak mengerjakan sendiri secara langsung disekolah).

Adapun hasil observasi, salah satu sekolah yaitu MIS Guppi 11 Talang Rimbo memiliki dokumentasi yang lengkap dalam hal penilaian, berbeda dengan sekolah lainnya tidak menunjukkan dokumentasi sehingga terkesan hasil belajar siswa diperoleh tanpa proses yang dianjurkan pada kurikulum 2013.

d. Teknik Penilaian dan Bentuk Instrumen

Berdasarkan hasil wawancara pada salah satu guru mengenai lembar teknik penilaian dan bentuk instrument ditinjau dari sthrengths (kekuatan) adalah Siswa lebih focus dalam mengerjakan isntrumen yang diberikan, siswa lebih lengkap dan leluasa mengeluarkan pendapatnya dalam menjawab instrume yang diberikan Akan tetapi hasil observasi mengenai teknik penilaian dan bentuk 
instrument tidak ada, belum jelas soalnya seperti apa, baik soal untuk mengukur aspek kognitif, afektif, maupun psikomotorik siswa.

\section{B. Pembahasan}

\section{Sthrengths (Kekuatan) Pelaksanaan Evaluasi Pembelajaran Berbasis Tematik}

RPP adalah detail rencana aktivitas pembelajaran untuk mencapai suatu Kompetensi Dasar tertentu, atau gabungan KD apabila dalam pembelajaran terpadu.. waktunya lebih singkat dibanding silabus, yaitu satu sampai tiga pertemuan. Dalam RPP inilah kegiatan pembelajaran apa yang akan dilakukan diuraikan.. dengan demikian, RPP akan menjadi pedoman praktis dalam pelaksanaan pembelajaran.

Dengan demikian, ketika guru mengembangkan RPP tujuan utamanya adalah untuk kepentingan dirinya sendiri, dalam rangka pelaksanaan tugas profesinya sebagai guru. RPP dibuat bukan sekedar untuk memenuhi kewajiban admininistratif, karena diminta oleh kepala sekolah atau karena akan disupervisi oleh pengawas. ${ }^{23}$

Adapun komponen - komponen RPP Pembelajaran Terpadu/ Tematik dapat dilihat di bawah ini :

a. Identitas (kelas, tema, alokasi waktu, tema)

b. Kompetensi dasar (dari mata pelajaran yang akan dipadukan dan sesuai tema)

c. Indikator hasil belajar (jabaran kemampuan khusus dari KD mata pelajaran yang dipadukan)

d. Prosedur Pembelajaran (menjelaskan pelaksanaan, pembelajaran yang meliputi kegiatan awal pembelajaran, kegiatan inti dan kegiatan akhir)

e. Metode, sumber dan media (yang digunakan dalam pembelajaran)

f. Penilaian (teknik, soal dan sistem skoring)

Hal ini sudah dapat dilihat jelas berdasarkan observasi dan dokumentasi di MI Rejang Lebong bahwa setiap guru sudah memiliki RPP yang disesuaikan dengan kurikulum yang diterapkan saat ini. Seluruh sekolah memiliki nilai kategori "Baik" dalam penyusunan RPP. Dengan demikian, diharapkan prosedur pembelajaran sesuai dengan yang terdapat dalam RPP.

Selanjutnya, wawancara yang dilakukan di MI Kabupaten Rejang Lebong mengungkapkan bahwa penilaian dalam kurikulum 2013 khususnya pembelajaran tematik sebenarnya sangat menunjukkan hal positif. Dimana tujuan penilaian autentik dilakukan secara terus menerus dan bersifat objektif. Hal itu ditunjukkan pada penilaian sikap pada jenjang SD/MI, kompetensi sikap spiritual mengacu pada KI-1 : menghargai dan menghayati ajaran agama yang

\footnotetext{
${ }^{23}$ Deni Kurniawan, 2014. Pembelajaran Terpadu Tematik (Teori, Praktik dan Penilaian), Bandung : Alfabeta, hal : 123
} 
dianutnya, sedangkan kompetensi sikap sosial mengacu pada KI-2; menghargai dan menghayati perilaku jujur, disiplin, tanggung jawab, peduli (toleransi, gotong royong), santun, percaya diri dalam interaksi secara efektif dengan lingkungan sosiall dan alam dalam jangkauan pergaulan dan keberadaaannya ${ }^{24}$.

\section{Weaknesses (Kelemahan) Pelaksanaan Evaluasi Pembelajaran Berbasis Tematik}

Salah satu bentuk pengembangan kurikulum yang akhir-akhir ini memperoleh perhatian secara sungguh-sungguh adalah pengintegrasian kurikulum yang hasilnya disebut sebagai kurikulum terpadu. Pembelajaran tematik seyogiyanya diterapkan pada tahun 2013 namun kenyataannya di berbagai sekolah khususnya MI Kabupaten Rejang Lebong menerapkan pembelajaran tematik di sekolah 3 (tiga) tahun terakhir ini itu terlihat penerapannya di kelas rendah atau kelas $1-3$ dan ada juga sebahagian sekolah sudah menerapkan sampai pada jenjang kelas tinggi atau $4-6$.

Pembelajaran tematik dibuat sesuai dengan kondisi siswa di kelas. Sehingga dibutuhkan kesiapan guru, siswa dan kemampuan guru secara khusus dalam pengembangan bahan ajarnya. Bahan ajar disusun secara tidak sederhana dikarenakan perpaduan dengan berbagai mate pelajaran. Kemungkinan selanjutnya adalah memerlukan biaya, waktu dan tenaga yang banyak. Oleh karena itu perlu adanya pengorganisasian yang lebih optimal sehingga dapat mengurangi kekurangan - kekurangan tersebut. ${ }^{25}$

Hal itu jugalah yang menjadi kelemahan pada evaluasi pembelajaran tematik yang terdapat di MI Kabupaten Rejang Lebong sehingga berdasarkan observasi yang ditemukan dilapangan pada proses penilaian yang hanya ditunjukkan dengan adanya format tanpa bisa menunjukkan proses pemerolehan nilai. Hanya 1 sekolah yang dapat menunjukkan hal tersebut. Selanjutnya, pada proses pelaksanaan pembelajaran strategi yang digunakan oleh guru tidak sesuai dengan format Rencana Pelaksanaan Pembelajaran (RPP) yang sudah dikategorikan "baik". Sehingga tujuan penilaian autentik tersebut secara tidak langsung tidak sesuai dengan pedoman kurikulum 2013.

\section{Opportunities (Peluang) Pelaksanaan Evaluasi Pembelajaran Berbasis Tematik}

Pada proses pembelajaran berbasis tematik terdapat kegiatan inti yang diharuskan untuk guru menvariasikan startegi pembelajaran sehingga diperlukan kreatifitas guru. Guru yang memiliki kreatifitas yang tinggi akan menciptakan ruang belajar yang bermakna. Siswa akan terlihat aktif dan mampu mengungkapkan imajinasi dan argumennya dalam mengemukakan pendapat. Sehingga student oriented terciptakan. Guru hanya menyadi fasilitator. Proses

\footnotetext{
${ }^{24}$ Rusman, M.Pd. 2015, Pembelajaran Tematik Terpadu Teori, Praktik dan Penilaian, Jakarta : Rajawali Press, hal 271

${ }^{25}$ Op. Cit Hal 70-71
} 
pembelajaran yang baik akan meghasilkan out put yang baik pula. Itu terlihat dari evaluasi yang dilakukan oleh guru.

Evaluasi adalah proses sistematis pengumpulan, pengolahan dan penyimpulan informasi tentang suatu objek, untuk selanjutnya diberikan pertimbangan nilai atas objek tersebut berdasarkan pada suatu kriteria tertentu. Dengan demikian, substansi komponen evaluasi ada tiga yaitu objek, judgement, dan kriteria.

Objek, artinya hal yang akan dinilai. Untuk bisa memberikan nilai yang tepat, perlu informasi yang cukup tentang objek yang bersangkutan. Oleh karena itu, perlu data yang memadai yang mampu menggambarkan keadaan objek yang bersangkutan. Judgement, artinya proses pertimbangan yang dilakukan oleh penilai untuk menentukan nilai atas suatu objek. Dalam proses pertimbangan ini, penilai membandingkan sejumlah data/informasi tentang objek yang berhasil dikumpulkan dengan kriteria atau standar tertentu. Kriteria itu sendiri adalah ketentuan minimal untuk menentukan suatu posisi nilai atau kualitas tertentu

Hal ini juga terlihat dari wawancara yang dilakukan pada MI Kabupaten Rejang Lebong mengungkapkan penilaian pada kurikulum 2013 sangat memberikan peluamg sangat objektif pada penilaian siswa sehingga diperoleh kognitif, afektif dan psikomotorik. Hal ini diperoleh dari teknik penilaian yang tertulis maupun lisan.

\section{Threats (Ancaman) Pelaksanaan Evaluasi Pembelajaran Berbasis Tematik}

Kurikulum 2013 merupakan hal yang baru bagi guru. Perubahan kurikulum yang sering terjadi membuat guru harus bersikap cermat dalam menghadapinya. Hal itu membuat ancaman yang sangat dikhawatirkan dalam proses pelaksanaan pembelajaran tematik. Ketidaksiapan guru akan perubahan kurikulum membuat guru senior khususnya tetap menggunakan sistem yang lama.

Ancaman terlihat pada Rencana Pelaksanaan Pembelajaran (RPP) yang dimiliki sekolah terstruktur tanpa menyesuaikan dengan kemampuan masingmasing siswa. Itu terlihat dari RPP yang dimiliki setiap sekolah nyaris sama. Selanjutnya RPP yang baik disajikan tidak selamanya sesuai dengan proses pembelajaran yang berlangsung.. berbagai pendapat juga mengatakan ketidak siapan guru dalam menjalankan kurikulum 2013 akan berimbas kepada siswa. ditinjau dari sistem penialaian masih banyaknya guru yang belum dapat memperlihatkan prosedur penilaian siswa sehingga pada RAPOT sekolah masih diragukan apakah itu dilihat dari penilaian keseharian siswa. Apalagi dalam proses penilaian yang bersifat afektif.

\section{SIMPULAN}


1. Sthrengths (Kekuatan) Pelaksanaan Evaluasi Pembelajaran Berbasis Tematik

Rencana Pelaksanaan Pembelajaran (RPP). Semua Madrasah Ibtidaiyah sudah menyesuaikan dengan format berbasis tematik. Secara pelaksanaan semua guru sudah pada kategori "Baik" dan dalam proses penilaian semua guru menyadari akan kekutaannya di kurikulum 13 karena menunjukkan penilaian secara sistematis dan objektif.

2. Weaknesses (Kelemahan) Pelaksanaan Evaluasi Pembelajaran Berbasis

Tematik

Proses penilaian yang hanya ditunjukkan dengan adanya format tanpa bisa menunjukkan proses pemerolehan nilai. Hanya 1 sekolah yang dapat menunjukkan hal tersebut. Selanjutnya, pada proses pelaksanaan pembelajaran strategi yang digunakan oleh guru tidak sesuai dengan format Rencana Pelaksanaan Pembelajaran (RPP) yang sudah dikategorikan "baik".

3. Opportunities (Peluang) Pelaksanaan Evaluasi Pembelajaran Berbasis

\section{Tematik}

RPP diharapkan pendidik menyesuaikan kondisi kelas masing-masing sehingga akan menghasilkan proses pembelajaran kreatif yang baik. ditinjau dari penilaian sangat memberikan peluang baik untuk guru maupun siswa. Bagi guru sistem penilaian yang terdapat pada kurikulum 2013 menuntut siswa baik secara kognitif, afektif dan psikomotorik. Dan peluang yang terdapat pada teknik penilaian dan bentuk instrument adalah bervariasinya bentuk soal baik secara tertulis maupun secara lisan.

4. Threats (Ancaman) Pelaksanaan Evaluasi Pembelajaran Berbasis Tematik

Rencana Pelaksanaan Pembelajaran (RPP) yang dimiliki sekolah terstruktur tanpa menyesuaikan dengan kemampuan masing-masing siswa. Itu terlihat dari RPP yang dimiliki setiap sekolah nyaris sama. Selanjutnya RPP yang baik disajikan tidak selamanya sesuai dengan proses pembelajaran yang berlangsung.. berbagai pendapat juga mengatakan ketidak siapan guru dalam menjalankan kurikulum 2013 akan berimbas kepada siswa. ditinjau dari sistem penialaian masih banyaknya guru yang belum dapat memperlihatkan prosedur penilaian siswa sehingga pada raport sekolah masih diragukan apakah itu dilihat dari penilaian keseharian siswa. Apalagi dalam proses penilaian yang bersifat afektif.

\section{DAFTAR PUSTAKA}

Armawati, Setia. dkk, Evaluasi Program Pembelajaran Tematik Integratif Kelas 1 Sekolah Dasar Pelita Bangsa. Jurnal : FKIP UNILA, Lampung.

Azwae, Saifuddin. 2007. Metode Penelitian . Yogyakarta : Pustaka Pelajar.

Hamzah, Ali. Evaluasi Pembelajaran Matematika. Jakarta : Raja Grafindo Persada http://www.kemdiknas.go.id/kemdikbud/, Kamis, 19 Oktober 2017, Pukul 14.12 WIB 
22| Ar-Riayah : Jurnal Pendidikan Dasar Vol. 3, No. 1, 2019

Ibnu Badar al-Tabany, Trianto. 2015. Desain Pengembangan Pembelajaran Tematik,. Jakarta : Prenadamedia Group.

Kamus Bahasa Indonesia, 2004

Kementerian Pendidikan dan Kebudayaan. 2013. Kurikulum 2013 ; Rasional, Kerangka Dasar, Struktur, Implementasi dan Evaluasi Kurikulum. Jakarta : Kemendikbud,

Kementerian Pendidikan dan Kebudayaan, 2013, Panduan Teknis Penilaian di Sekolah Dasar

Mulyasa, E 2013. Pengembangan dan Implementasi Kurikulum 2013. Bandung: PT Remaja Rosdakarya.

Panduan Akademik 2017. STAIN Curup

Rangkuti, Freddy. 2004. Analisis SWOT Teknik Membedah Kasus Bisnis. Jakarta : PT. Gramedia

Suke Silverius. 1991. Evaluasi Hasil Belajar dan Umpan Balik. Jakarta : Grasindo.

Sugiyono. 2011. Metode Penelitian Pendidikan : Pendekatan Kuantitatif dan Kualitatif dan R \& D. Bandung : Alfabeta. 2014. Memahami Penelitian Kualitatif. Bandung: Alfabeta.

Yuniasih, Nury. dkk,2014. Analisis Pembelajaran Tematik Pada Kurikulum 2013 di SDN Tanjungrejo 1 Malang. Jurnal : Mimbar Sekolah Dasar . 